\title{
International academic mobility: the attraction factors of Brazilians students in Spain
}

\author{
Kingeski, Luciano and Olivella Nadal, Jordi
}

Department Business Organization, Polytechnic University of Catalonia, Spain.

\begin{abstract}
The mobility of university students abroad is a phenomenon of great importance in the context of globalization and internationalization of higher education. Certain factors, such as the image of the institution, the country, the city, the evaluation of the study program, the cost, selection processes and even personal resources can determine the destination country. This article seeks to identify the attraction factors for which Brazilian university students choose Spanish universities to carry out their higher education. An exploratory study of a qualitative nature was conducted, a semi-structured questionnaire applied to twenty-eight Brazilian students of official rank: graduation, master's degree and doctorate. Data analysis was based on the assessment of attraction factors. The results indicate that the language, the tradition of the Spanish universities, the scholarships of the country of origin and the more flexible selection processes are important factors in the decision of these subjects. Spain is an option for many international students and the flow of Brazilian students to this country is significant, the authors also consider that these flows may be much larger in the future.
\end{abstract}

Keywords: Brazilian students; academic mobility: internationalization, attraction factors. 


\section{Introduction}

Throughout history, we can see the gradual increase of students moving to other countries, attracted by a better academic and professional background. We live in the age of information and knowledge and the deeper part of human change is in the cultural dimension, as one of the great riches of today's societies. Thus, the increasing internationalization of all types of activities makes international experience increasingly necessary and at the same time more accessible to an increasing number of people. In the period between 1975 and 2012, the number of students who went to other countries to study higher education increased from 800.000 to 4.5 million (OECD, 2014).

In percentage terms, the United States and England are the destinations most sought by foreign students, being $16.4 \%$ and $12.6 \%$. They also carry out an important activity to attract the same type of students: Germany, with 6.3\%; France, with 6\%; Australia, 5.5\%; Canada, $4.9 \%$ and Japan with 3.3\%. Spain currently accounts for 2.5\% (OECD, 2017). In 2014-2015 approximately 49.053 study visas were issued in Spain, of which 20.062 are from Latin America and the Caribbean, representing approximately $41.64 \%$ of foreign students in Spain (OECD, 2017). Between the periods 2009 to 2012 there was an uneven evolution of Latin American students in Spain and a general fall between the years of 2012 and 2014, one of the indicative ones was the economic crisis that passed the country in this period. Despite the reduction in the flow of Latin American students in Spain, in all of them the figures are significant, being one of the first destinations of university studies. Although the percentage of Brazil and Mexico is lower than the others, the Brazilian university system is important and has the specificity of the language, and Mexico has a geographical proximity to the United States. Through these data, one perceives a new scenario in higher education.

Since the mid-twentieth century the experience of studying abroad has been exceptional, limited to groups with high economic power or high educational performance, where in the last twenty years this experience has been to acquire an increasingly common base for a higher percentage of students. As a result of this increased mobility, there are new offers of undergraduate programs, universities and new poles of attraction, especially in countries with better technology and training for business management, as in the case of new actors in this scenario, for example Singapore, United Arab Emirates, Spain and others. These countries can play an important role in the future of university education for these young people. These transformations remain intense. According to the Ministry of Education, Culture and Sport, in Spain alone, during 2014-2015, the number of offers of master's courses was 3.661, 9\% more than in the previous year. Of these, 2.979 are in public universities and 709 in private universities, and 1.036 doctoral programs, of which 967 are in public universities and 69 in private universities. The issue of the internationalization of university students in Spain is little explored in academia. Currently, little is known about 
students' performance, their main reasons for choosing the country, the evaluation of their experiences and their future projects, are those gaps that require the necessity of studies of this nature, given the great representation of this public. So, this article seeks to identify and analyze the reasons that lead Brazilian students to decide on the possibility of pursuing their university studies in Spain. This study is part of a research that is being developed through the Doctoral Program in Business Administration of the Polytechnic University of Catalonia (ETSEIB-UPC), which began in march 2015.

\section{Review of the literature}

This article confines itself to studying the attraction factors of Brazilian students, that is; Academic motivation, term adopted by many researchers. Therefore, the evolution of the concept of motivation was not explored, but it is known that the first studies began in the mid-1950s with the advent of scientific management. As for the motivations for studies abroad, several reasons may explain the rapid growth of student interest. At the individual level, overseas study helps the person to cope with the demands of the job market more successfully, also increases the international dimension at work and improves his or her career in general (TEICHLER, 2007). The following are the main studies related to specific cases.

One way to classify these factors of attraction is the contribution of (Altbach, 1998), which differentiates them from "push-pull" factors. The "push" factors operate within the country of origin before the decision to study abroad, and pull factors within the host country to make it more attractive than other potential destinations. This classification has been widely adopted by subsequent studies and continues in this work. Currently, there is a wide literature with authors who have adopted the "push-pull" fundamentals, mainly in countries such as: USA. United States, United Kingdom, Australia and China. The main authors and attraction factors identified in their studies: Altbach (1998) cost of mobility, employment rate in the host country, geographic distance, environmental environment, quality of institutions, financial support, perspectives of professional future, economic situation of the country of origin, language, intercultural training of the institution of origin, the family, interest in mobility - Mazzarol \& Geoffrey (2002) the language, an estimate that a course conducted in a foreign country is better than in your home country, the ease of access to the course and, mainly, the reputation that this experience can bring in the future - Kazlauskiene \& Rinkevičius (2006) "brain-drain" Professional attraction in foreign countries, socioeconomic conditions. Other factors, such as ecological conditions and family reunification, play a much smaller role in this phenomenon of brain drain - Mei Li \& Mark Bray (2007) the motivations in pose of the academic and professional growth, the economic benefit, the individual internationalization and the improvement of the social status - Molly (2007) Future migration opportunities after graduation education, high quality courses and the cost 
of living - Bodycott (2009) significant differences were found between the role and approach of students and their parents in the first and last stage of decision making (tradition and values) - Wilkins, Balakrishnan \& Huisman (2012) the study incorporates two different sets of "push-pull" factors and sought to better understand current and potential students, in order to implement segmentation techniques in their marketing activities and finally Cao, Zhu \& Meng (2016) future career prospects, the quality of institutions, the cost of mobility and climate in the host country. Geographic distance emerged as an unfavorable attraction and a significant risk factor. However, the impact of the parents, the language and the intercultural training institutions of origin emerged as favorable dynamic factors. And the country's economic situation emerged as an unfavorable "push" factor.

\section{Methodology}

For the development of this research, in-depth interviews were conducted with Brazilian students who at the time of interviewing reside in Spain, with the objective of obtaining an official degree (master's or doctorate) in a Spanish university. So, exchange students were not considered in the study. For the election of the interviewees we looked for students who recently made the decision process in relation to the country of destination in question, so that one can think that they are well aware of the different elements of this decision at the present moment. This is what differs in general from exchange students who in most cases migrate to other countries through agreements from universities that study with the destination universities. Due to the lack of previous studies, we chose to conduct in-depth interviews, a qualitative and semi-structured approach. In this way we tried to identify aspects that could not be known at the beginning of the research. For the development of the interviews, a questionnaire was elaborated based on the factors identified in the literature. The questionnaire was structured in four blocks of questions: demographic data, country election factors, university election factors, and course selection factors. This was first applied in pilot interviews (in group and individual), then adjusted according to the results obtained from these first tests and replicated to 28 Brazilian students. This stage ends with the transcription of the audios of the interviews with the help of the otranscribe tool, then the interpretation and analysis of the identified factors.

\section{Results}

In order to get closer to these students, the following sources of contacts were used: Association of Brazilian Researchers and Students in Catalonia (APEC), Embassy of Brazil in Madrid, Center for Brazilian Studies at the University of Salamanca (CEB) and indications from other students. The students interviewed come from several regions of Brazil: Minas 
Gerais, Goiás, São Paulo, Distrito Federal, Rio Grande do Sul, Paraiba, Pernambuco, Ceará, Mato Grosso do Sul, Santa Catarina, Espirito Santo, Paraná and Bahia. In relation to the sex of the interviewees, there is an inclination to the female sex (20), while the male sex (8). However, these data only inform the condition of the interviewees in this exploratory study, but cannot be considered as indicative of trends among the population of Brazilian students who move to Spain. As for the age of the interviewees, there was a wide distribution, with young students ranging from 20 years to 55 year old students. Age is an important factor in the study decision process abroad, because the trajectory, the responsibilities and the phase that each of the groups is very different. The Universities that carry out their studies in Spain: Barcelona: Polytechnic University of Catalonia and Autonomous University of Barcelona and University Pompeu Fabra, Salamanca: University of Salamanca, Zaragoza: University of Zaragoza, Valencia: University of Valencia, Cantabria: University of Cantabria, Balearic Islands: University of the Balearic Islands and Madrid: University Complutense of Madrid. With respect to the cities and provinces of origin, students from thirteen (13) different provinces were contacted. The flow of Brazilian students to Spain is not concentrated in a specific area of the country and the interest in academic mobility is made both by students from poorer areas and more developed areas in the educational field. Students from different areas of knowledge and modalities (bachelor's, technologists and engineering) were identified. The training of the interviewees in the country of origin: Business Administration, Literature, Biology, Tourism, Dentistry, Music, Social Communication, Geography, Oceanography, Physiotherapy and a more accentuated presence to the Right to Students course (5) 17, 86\%. In this sample, there were (1) $3.57 \%$ undergraduate students, (17) $60.72 \%$ undergraduate and (10) $35.71 \%$ undergraduate. In relation to the area of knowledge, there is an accentuated search for courses in the areas of Human Sciences and Applied Social Sciences. Then, in the (Table 1.) the cities, courses and universities of studies in Spain are presented. 
Table 1. Distribution of students by cities and courses

\begin{tabular}{|c|c|}
\hline $\begin{array}{l}\text { Distribution } \\
\text { and cities }(n: 28)\end{array}$ & Courses (Oficial names) \\
\hline Barcelona (7) & $\begin{array}{l}\text { Doctorado en Historia del Arte y Musicología, Máster de Criminología, } \\
\text { Política Criminal y Sociología Jurídico-Penal (UB); Doctorado en Traduc- } \\
\text { ción y Estudios Interculturales (UAB); Doctorado en Derecho (UPF), } \\
\text { (UAB); Doctorado en Políticas Públicas y Transformación social (UAB); } \\
\text { Doctorado en Sostenibilidad, (UPC). }\end{array}$ \\
\hline Salamanca (11) & $\begin{array}{l}\text { Máster en Economía de la empresa, Doctorado en Economía de la empresa, } \\
\text { Máster en Antropología de Iberoamérica, Doctorado en Antropología de } \\
\text { Iberoamérica, Doctorado en Educación, Máster en Derecho, Doctorado en } \\
\text { Linguiística-lengua española, Doctorado en Ciencias de los Materiales and } \\
\text { Doctorado en Estudios Latinoamericanos (USAL). }\end{array}$ \\
\hline Zaragoza (2) & Doctorado en Ordenación del Territorio (USAL). \\
\hline Valencia (1) & Doctorado en Comunicación, Universidad de Valencia (UV). \\
\hline Madri (1) & $\begin{array}{l}\text { Máster en Microbiología y Parasitología, Universidad Complutense de } \\
\text { Madrid (UCM). }\end{array}$ \\
\hline Santander (1) & $\begin{array}{l}\text { Doctorado en Ingeniería de Costas, Hidrobiología y Gestión de Sistemas } \\
\text { Acuáticos, Universidad de Cantabria (UC). }\end{array}$ \\
\hline $\begin{array}{l}\text { Palma de Mallor- } \\
\text { ca (1) }\end{array}$ & Máster Oficial en Neurociencias, Universitat de les Illes Baleares (UIB). \\
\hline Valladolid (3) & $\begin{array}{l}\text { Doctorado en Linguiística Aplicada, Universidad de Valladolid, Máster en } \\
\text { Administración de Industrias Culturales, Máster en Investigación en Cien- } \\
\text { cias de la Visión (UVA). }\end{array}$ \\
\hline Logroño (1) & $\begin{array}{l}\text { Grado en Administración y Dirección de Empresas, Universidad de la Rioja } \\
\text { (UR). }\end{array}$ \\
\hline
\end{tabular}

UAB: Universitat Autònoma Barcelona; UB: Universitat de Barcelona; UPC: Universitat Politècnica de Catalunya; UPC: Universitat Pompeu Fabra; USAL

Source: Interview data 


\subsection{Interview Results}

This analysis was carried out from the main factors identified in the previous studies and these were adapted to the specific case and grouped in a simple scale of 3 levels (zero, 1 and 2) that it was possible to obtain the results for each factor. The following are the main factors identified in the in-depth interviews and the first conclusions of the study: $-\underline{S e-}$ lection process: The difficulties of entering postgraduate programs in Brazil are a factor mentioned by many of the interviewees (22). The number of vacancies is limited, analysis of the academic trajectory and the rigidity of the selective processes were highlighted by the interviewees. - Country choice: Spain was the first choice for half of the students (14). The others sought other countries: England, USA and Germany. However, the difficulty of the language and the mobility costs (tuition, fees and lodging) were the barriers presented by them. Portugal was also evaluated as an option by (3), but for these, the changes would not be as significant in their curriculum. - University rankings: Only (7) of the students worried about this item. Factors such as tradition and prestige of Spanish universities were important to them at the time of the decision. All interviewees believe that obtaining a degree at a university abroad can be a differential when returning to their country of origin. - Influence of the environment: The indication of the country, the university and the course, most of the students (24), mentioned that their decision process occurred with the indication of teachers in their environment, research groups and friends. - Language: One of the most important factors mentioned in this decision process, where mentioned how, very important to carry out their studies abroad. Of the total of (28) students, only one of them has the TOEFL (Test of English as a Foreign Language) certificate, which is one of the requirements made by many graduate programs in Brazil. - Scholarships: Only (2) carry out their post-graduate studies with their own resources. All others are financed by Santander Bank and Foundation Capes / CNPq. - Cost of mobility: Spain has a lower cost of living compared to countries such as the United States and England, which are the main destinations for foreign students in the world, a factor taken into account by virtually all at the moment of decision-making. - Tradition and prestige: The tradition and prestige of Spanish universities were identified by all the interviewees.

\section{Conclusions}

This in-depth analysis with 28 Brazilian university students points to aspects considered fundamental in the decision-making process for studies abroad, in particular the country of Spain. Considering the subject in question, its relevance in the academic world is perceived by an empirical study and a contribution to existing literature, however, it is necessary to cover other identified gaps and also to be exploited by different researchers. Through the theoretical review, it is possible to identify and analyze the international mobility in differ- 
ent countries and compare it with the reality of this particular case, especially to the specific cases that adopt the "push-pull" fundamentals. Similarities of some of the attraction factors of these studies are observed, for example: Mazzarol \& Goffrey (2002) with the importance of language, more flexible selection processes and good reputation in the country of origin after the experience, Li \& The importance of the environment (family and friends) for decision making, and finally Molly (2007) and Cao, Zhu \& Meng (2016) with Mey \& Bray (2007) "social status", Bodycott (2009) and Chen \& Zimitat the concern related to the cost of living. In particular, the study by Altbach (1998) was fundamental for the organization of the data collection instrument (semi-structured questionnaire) and for the identification and analysis of the attractiveness factors of Brazilian students in Spain, where it was noted interviews the importance of the factors of attraction such as: interest in the country Spain for studies abroad as a highly relevant option, scholarship systems, the influence of the environment, the cost of mobility and approach to the language of origin.

\subsection{Limitations and Future work}

One of the limitations of this type of research is the difficulty of obtaining the information of the subjects, in this case, the location of the students and the contact becomes difficult and limited, insofar as the institutions and organizations (universities and embassies) are not authorized to provide specific information about them. One of the obstacles faced by students of this type of human mobility is that there is little data to measure it, so that, in order to know more about the trajectories of the students after finishing the studies, qualitative type, focused on disciplinary areas and educational levels (Trejo and Sierra, 2014). So it is necessary to implement different approach strategies. (SANDOVAL, 2014). The exploratory nature of research, rather than definitive and conclusive answers, leaves open a number of questions, the answers of which require further analysis. Therefore, the next step of this research is to contrast the data through a quantitative sample that has been applied in recent months (December 2017 to March 2018).

Finally, the nature of the research, rather than definitive and conclusive answers, leaves open a number of questions, the answers of which require further analysis. Therefore, the next step of this research (in development), is to compare the data through a quantitative sample (mixed method) to a greater number of students with these same characteristics.

\section{References}

Altbach, P. G. (1998). Comparative Higher Education: Knowledge, the University, and Development. Hong Kong: Comparative Education Research Centre; The University of Hong Kong, p. 240. 
Bodycott, P. (2009). Choosing a higher education study abroad destination: What mainland Chinese parents and students rate as important. Journal of Research in International Education, 8(3), 349-373. DOI: 10.1177/1475240909345818

Cao, C., Zhu, C. and Meng, Q. (2016). A Survey of the Influencing Factors for International Academic Mobility of Chinese University Students. Higher Education Quarterly, 0951-5224.

Chen, C.H., Zimitat, C. (2006) "Understanding Taiwanese students' decision- making factors regarding Australian international higher education”. International Journal of Educational Management, Vol. 20 Issue: 2, p.91-100.

Kazlauskienè, A., \& Rinkevičius, L. (2006). Lithuanian "brain drain” causes: Push and pull factors. Engineering economics, 46(1), 27-37.

Li, M. and Bray, M. (2007). Cross-Border Flows of Students for Higher Education: PushPull Factors and Motivations of Mainland Chinese Students in Hong Kong and Macau. Higher Education, 53(6), pp. 791-818.

Mazzarol, T., Soutar, Geoffrey N. (2002). The "Push-Pull" Factors influencing international student selection of education destination. International Journal of Educational Management.

Ministerio de Educación y Deporte. Datos y cifras del sistema universitario español. Disponible $\quad$ em: http://www.mecd.gob.es/educacion-mecd/areaseducacion/universidades/estadisticas-informes/datos-cifras.html Acesso em: 28 de janeiro de 2016.

Molly, Y. (2007). What attracts mainland Chinese students to Australian higher education. International Journal of Educational Management.

OECD (2014) Education at a Glance 2012: OECD Indicators. Paris: OECD Publishing.

OECD (2017) Education at a Glance 2015: OECD Indicators. Paris: OECD Publishing.

Sandoval, María C.P. (2014). La Movilidad de Estudiantes de Posgrado de Venezuela y México a Canadá: Un Estudio Exploratorio. Revista Latinoamericana de Educación Comparada.

Teichler, U. (2007). The Flexible Professional in the Knowledge Society: New Demands on Higher Education. Project Supported by the VI Framework Programme of the EU, pp. 199-220. Maastricht: Maastricht University.

Trejo, A.P. y Sierra-Paycha, C. (2014), "Gestión de la movilidad estudiantil en Estados Unidos. Dimensionando a los estudiantes colombianos y mexicanos”, Journal Camino Real, Estudios de las Hispanidades Norteamericanas, Instituto Universitario de Investigación en Estudios Norteamericanos "Benjamin Frankiln". Universidad de Alcalá, 6, número 9.

Wilkins,S., Balakrishnan,M.S.\& Huisman,J. (2012). Student Choice in Higher Education: Motivations for Choosing to Study at an International Branch Campus, International Journal of Educational Management. 